UNRAM Law Review is licensed under a Creative Commons Attribution 4.0 International License, which permits unrestricted use, distribution, and reproduction in any medium, provided the original work is properly cited. p-ISSN: 2548-9267 | e-ISSN : 2549-2365, Open Access at : http://unramlawreview.unram.ac.id/index.php/ulr

\begin{tabular}{c|c|c|c|c|}
\hline Volume & Issue & Page & October & p-ISSN: 2548-9267 \\
4 & 2 & $145-152$ & 2020 & e-ISSN : 2549-2365
\end{tabular}

\title{
Criminalization of Human Trafficking; Assessment of Victims in Judges' Verdict for Deviant Sex services
}

\author{
A Djoko Sumaryanto \\ Law Faculty, Bhayangkara University \\ Email: adjokosum@gmail.com
}

\begin{abstract}
The current criminal law still adheres to the concept of Daad Dader Strafrecht, therefore, the existence of crime victims could not betouched by the law which implemented in every judge's decision,such as the event that a husband sells his wife for sex or threesome, the wife position here as the victim, this research was done by using legal research of normative law, which applies statute approach and case approach, by examining Sidoarjo State Court Verdict Number: 889/Pid. Sus/2018/PN.SDA, and it obtained several results, first inaccurate application of law and weak point of views of victim of crime. It can be concluded that after examination of legal facts, review the literatures and analyze it based on the cases, this work suggest husband activities on selling his wife by illegal sex/threesome should not be included as human trafficking. Since normatively, it is not relevant, furthermore the condition of family is not really well.
\end{abstract}

Keywords: Criminal Law; Crime Victim; Verdict.

\section{INTRODUCTION}

Slavery hadexisted in the history of Indonesia, and women are complementary of governmental system.In the era of ancient king and the concept of power, a king was described as great and noble; as the king had full power, and it reflected in the number of mistresses he have.

Indonesia is a rule of law country which has function to protect and uphold Human Rights as stated in Article 27 paragraph (1) of 1945 Constitution of the Republic of Indonesia which stated that "Every citizen has the same position in Law and Government and obliged to obey the law without exception" or known as Equality before the law. AsRoscoe Pound ${ }^{1}$ theory, the law is a tool to change people (Law is a Tool of Social Engineering), that become the main thinking of law to organize the interests of society.

In this independent era, especially in reformation era, communication and information technology can be used by irresponsible people to obtain the advantagesespecially on woman as victim. Actually, human trafficking is not a new problem, however, these last view years it is once again appeared with a modus operandi.

Several factors which causes human trafficking are gender discrimination, cultural practices that develop in Indonesian, young marriage, secret marriage, conflict and disaster,

\footnotetext{
${ }^{1}$ Roscoe Pound. (2012). The Ideal Element in Law, The Ideal Element In Law, 2012, p.3.
} 
school dropout, globalization, law system and weak enforcement, disharmonious families, low religious moral values, and others.

Developments inside and outside particular human being will affect the tendency and ability to engage in despicable behavior, harmful and destroy the justice, moreover human will influence other human around by physical, psychological and social harmful.

Human trafficker has fast development and become a cross-border syndicate very subtly ensnares its victim and cruelly exploits in various ways therefore, the victim becomes helpless ${ }^{2}$.

The most influenced factor of human trafficking is because the high amount of demand toward the job of informal sector which does not need special requirements, who are willing to be paid relatively low wages and do not require complicated work agreements, thus encouraging traffickers to do trafficking business.

According to the constitution Article 1 Number 21 of 2007 of Eradication of the Crime of Human Trafficking, human trafficking described as:

"The attitude of recruiting, transporting, holding, sending, transferring or receiving a person with threats of violence, the use of force or a vulnerable position, bondage or giving payment or benefits, to obtain the consent of person in control of that person, whether carried out within the country or between state, for the purpose of exploitation and resulting in exploitation of people."

There is several reason of people become victim, it is because they know nothing, incautious, weak or victim misfortune. Victim can be a real victim, that means she is only a victim and did not do any wrongdoing or guilty victim which means the victim is a part of criminal act. Hentiginside ${ }^{3}$,consider that there are a type of victim role to cause a criminal action, such as:

a. The victim intended the crime to occur;

b. Losses due to criminal acts may be victimized in order to obtain greater benefits

c. The adverse effect of victim might be the result ofcooperation between the perpetrator and the victim

Several cases of women trafficking are, woman often being hired in dangerous sector, forbidden job, drug couriers, forced labor, domestic assistance, victims of sexual exploitation in pornography and prostitution.Countermeasures mobilized through various legal instruments, international conventions, and multilateral agreements.

Based on some definitions above, recently deviant sex services or threesomes have occurred and are currently being handled by Surabaya Police.The case in AgusAriandi was captured by the police at a hotel in Sarangan, East Java. The husband sells his wife for a threesome. It is also weighted by the fact that their marriage was unregistered, and the wife was pregnant ${ }^{4}$.

Based on the explanation above, in order to make a research problem, focused and related matter of "Assessment of Victims in Judge Verdict" Furthermore, it will be discussed according to the sub-study, legal fact, consideration and decision of judge, as well as the analysis of victim in judge's verdict on judge's decision number : 889/Pid.Sus/2018/PN Sda

Research method applies in this work waslegal research which done to examine the norm inside legislation and court decisions. The approach of this research is statute approach which

\footnotetext{
${ }^{2}$ IOM Indonesia. 2006. Fenomena Trafficking Manusia Dan Konteks Hukum Internasional. Jakarta.

${ }^{3}$ Rena Yulia. (2010) . Viktimologi: Perlindungan Hukum Terhadap Korban Kejahatan . Bandung: Graha Ilmu. P. 81.

${ }^{4}$ Hilda Meilisa, "Istri Yang Dijual Suami Untuk Threesome Di Sarangan Hamil 6 Bulan," DetikNews, last modified 2019, From: https://news.detik.com/berita-jawa-timur/d-4668648/istri-yang-dijual-suami-untuk-threesome-di-sarangan-ham il-6-bulan. Accessed September 16, 2019.
} 
examine the relevant constitution and cases approach to examine a court ruling regarding a threesome case in Sidoarjo District Court

This research includes several legal entities such as:criminal code, human trafficking law, the Law on the Elimination of Domestic Violence and Sidoarjo District Court Decisionnumber : 889/Pid.Sus/2018/PN SDA) and secondary legal materials consist of literature/books, journals, research results, and articles that relevant to the title of the article.

The procedure of collecting legal materials carried out by systemizing legal materials, which obtained through offline literature and by searching online.

Management and analysis of legal materials through systematization and analysis was done by descriptive analysis, explain the results of analysis on victim and the application of law in judge's decision on deviant sex services (threesome) at Sidoarjo District Court.

\section{ANALYSIS AND DISCUSSION}

\section{Legal Facts in the Verdict Number 889/Pid.Sus/2018/PNSDA}

Related to the rise of deviant sex services/threesomes above this research tried to examine a case of husband selling his wife which happen in District court of Sidoarjo based on the law number: 889/Pid.Sus/2018/PNSDA, with several legal facts as below :

It was started when the defendant intended to seek profit by trading and using his wife commercially by offering massage services and having sex in a threesome. The defendant sought these services by using social media in this case, the defendant use Facebook Group, he offer threesome massage service, and one of group member interested and they continue their deals by messenger (inbox) and online media whatsapp, and from that chatting, defendant provide a payment charge for threesome services. The settled payment for a night threesome charge is Rp. 500.000 with a deal of Rp. 300.000 as a down payment and the rest will be paid after the transaction and the service done. On this process, the defendant forced his wife, the witness Aminah, to commit this act and threatened his wife that the defendant would scold his wife and that the attempt was made to pay the defendant's debt and credit. Therefore, Because of fear, witness Aminah wanted to commit the act and before the act was committed, the defendant gave AminahRp. 300,000, - (three hundred thousand rupiah) whose money came from witness/buyer Andre alias Titan.Furthermore, when they was having sex with a customer, Sidoarjo Police officers as witness Tessaloni, witness WawanHariSantoso, witness UtunUtami was conducted a raid and they were found in the room. Did an illegal activity in a state of naked, did a massage and threesomesex.

\section{Judges'Considerations and Rules}

Based on the legal fact above, judges will consider whether the defendant include as committing a criminal act or not and what a proper punishment for him. The defendant has been charged by Public Prosecutor with an alternative charge, thus, by the fact above, the panel of judges will choose the alternative judgment as what regulated in the law of human trafficking criminal act article number 2 with the aspects as below: 
1. Every person;

2. Who Recruit, transport, hold, send, transfer or receive someone with threats of violence, power abuse or vulnerable position, debt bondage orprovide payment or benefits, even by the agreement of control holder with a purpose to exploit a person in Indonesia.

Regarding the elements above, the Panel of Judges consider the following judgment:

- Every Person element

That "every person" which means an individual as a law subject obligated to be responsible of every criminal act accused by public prosecutor.

Which explained above, defendant identity as stated in indictment letter, is investigated person or a person who is submitted to the court, therefore there will no personal error or error in persona happen, and the Defendant is physically and mentally health, who can be responsible if his actions are proofed to be true, therefore the element of "every person" has been fulfilled.

- The element of recruited, transported, sheltered, delivered, moved or accepted another person by the threat of violence

Based on the fact consideration, it was revealed that the defendant has abused his wife's power or vulnerable position, for the purpose of exploitation by influencing his wife for economic reasons and it caused the victim willing to conduct a threesome, then this element is fulfilled. Thus, every aspects of human trafficking law were fulfilled, and then the defendant must be declared legally and proved to committed criminal act as charged in the indictment.

During the examination of defendant there should no excuses for forgiveness and justification, according to the law defendant is able to be responsible, found guilty and sentenced to a punishment that related to his actions.In this case defendant is subject to legal arrest and detention, the period of arrest and detention must be fully deducted from the imposed sentence.

In order to decide the punishment, it should be consider the aspect below:

- The Defendant's actions disturbed the society;

- The defendant's actions that did not respect his wife's dignity, cruel and inhuman

And there are several aspects to lighten the punishment:

- The defendant confessed his actions;

- The defendant behaved politely during the trial;

- The defendant has never been convicted and the victim forgave the defendant act.

\section{Judge Verdict on the Case Number 889/Pid.Sus/2018/PNSDA}

Based on article 2 Law Number 21 of 2007 regarding Human Trafficking, Law Number 8 of 1981 regarding Criminal Procedure Law and other laws and regulations related to this case, the Panel of Judges decided that:

1. Stated that the defendant are proved to break the law of Human trafficking;

2. Decide a punishment to defendant for 4 (four) years and 6 (six) month and payment for 120.000.000,- (a hundred and twenty million rupiahs), under the condition if the defendant cannot meet the payment, it is replaced by for 3 (three) months imprisonment;

3. Determine the period of arrest and detention as the accused has served, fully deducted from the imposed sentence;

4. Defendant keeps being imprisonment. 


\section{The Analysis Toward Judge Decision and the Victim}

Based on the consideration and judge decision above, the writer will give an explanation of review based on material criminal law victimology studies.As what it stated above, the process of criminal law enforcement intended tofocus on punishment to defendant while accommodating the rights and interests of victim. The prosecutor will maintain the case in order to make the justice for both criminal subject and the victim 5 . However, law enforcement by prosecutor has not been seen inSidoarjo district court's decision, means that the wife has become a victim of her husband's act of engaging deviant sex services (threesome) and also a victim of judge's decision (verdict) by imprisoning her husband because wife will not obtain any outcomes from his husband.

Based on the study of material criminal law, judge decision that refers to human trafficking law is not implemented well. Because between the defendant and victim, there are still an official status as husband and wife,therefore it implied on sanctions against the accused were too heavy, 4 (four) years and 6 (six) months and a payment of 120 MillionRupiahs. If we look at the background of philosophical formation or the motive of human trafficking that usually carried out by syndicates/ organizations against weak humans (women and children) which is carried out across countries and there is no relation between the defendant and the victim. While the case above committed by husband against his wife, or family members against other family members (in one family).

According to the study of victimologywhich based on the crime victim, judge in making his decision must pay attention to public interest, the community or the interests of aggrieved side.Practically on obtaining the decision, the judges use the interpretation of De Schutznorm 's theory. In brief, the theory of De Schutznormcan be statednot only causes of an act against the law, but from individual point of view it also causes harm to others.A person who commits an act against the law is only obliged to compensate if the violated law specifically aimed at protecting legal interests of other person who is violated ${ }^{6}$.

The position of crime victim who is basically the person who suffers the most in a crime, has not received adequate protection as provided by law to the subject of crime. Thus, when the subject of a crime has been sentenced by the court, the condition of crime victim seems to be completely ignored. While, theissueofjusticeandrespectforhuman rightsdoes not only applied to criminals' subject, but also victim sof the crime.

There is several reasons of people become victim, it is because they know nothing, incautious, weak or victim mis fortune. Victim can be a real victim, that means she is only a victim and did not do any wrongdoing or guilty victim which means the victim is a part of criminal act. ${ }^{7}$

Based on the protection factors, $\mathbf{M u l a d i}^{8}$, explained several reason that related to victim protection such as:

First, there are two kind of criminal process; in general is the authority of legislators, must be related to the principle of legality, which confirms that both poena and crimen must be applied before they decided a criminal punishment on a criminal subject, and the criminal

\footnotetext{
${ }^{5}$ Yulia, Viktimologi: Perlindungan Hukum Terhadap Korban Kejahatan.

${ }^{6}$ Komariah Emong Sapardjaja. (2002). Ajaran Sifat Melawan Hukum Materiil Dalam Hukum Pidana Indonesia. Band ung: Alumni, p.71.

${ }^{7}$ Lieta Vina Tania. (2018). “Analisis Perspektif Viktimologi Terhadap Korban Tindak Pidana Pemalsuan Dokumen Tenaga Kerja Wanita,” Jurnal Fakultas Hukum Universitas Lampung Bandar Lampung 6, Number 4.

${ }^{8}$ Yulia, Viktimologi: Perlindungan Hukum Terhadap Korban Kejahatan, p.81.
} 
process in concrete meaning is a process related to punishment decision through the penitentiary infrastructure (judges, prison officers, etc).

Second, begin from other arguments that prioritizing legal protection of crime victims. There are social contract argument and social solidarity argument. The countrycan be stated as having monopoly on all social reactions toward crime and prohibits the personal actions; therefore if a crime occurs and causes victims, a country must be responsible for giving full attention to the victim's need.

Third, the problem of victim regulation usually related to a purpose of punishment, which is the conflict settlement.Conflict settlement which caused by criminal activity, to restore balance and bring back sense of peace in the middle of society.

In field of criminal law, if the is an act against law occurs, there are two opposites face each other is prosecutor on behalf of state and representthe importance of victims, and the other side is the defendant which accused against the law'.

Judge's consideration stated that based on the facts above, It was revealed that defendant had abused his wife's in vulnerable position for the purpose of exploitation by affect his wife for economic reasons therefore, the victim willing to conduct a threesome/deviant sex with another person.The details will be explained as; the husband forced his wife and told her it is because economic reason, therefore his wife agrees. As the wife already know and understand that she has become a victim within all the consequences (obeying her husband, to solve family economic problems, even by doing a deviant act)

Violenceact that committedbythe husbandtowardshiswifeis a violencethatoftenoccurs in society.This is a result of relationship in household when men consider as more superior than women, thus it makes a system of men having more control over women, it can cause violence act. Domestic violence is refers to an act that based on gender, it can cause physical, sexual and psychological suffering; it can be coercion or arbitrary deprivation of freedom whether in public or private environment. ${ }^{10}$

Regarding the protection toward victim,Philipus M. Hadjon ${ }^{11}$, explainthat there are two kinds of protection facilities, preventive legal protection and repressive legal protection. Preventive legal protection has a close relation with the principle of freisermessenas general legal protection. While repressive legal protection in Indonesia handled by the court within general judiciary, government instances which consist of administrative appeals and special institution.

In Indonesian criminal justice system, the position of public prosecutor often being ignored and cause dissatisfaction from their family with the demands of prosecutor and judge's decision. This aspectcaused by procedurally the victim did not have the opportunity to express his dissatisfaction regarding the prosecutor's demands and judge's decision. Victim protection is important because the victim's suffering has not ended yet only by an imposition and punishment of criminal subject. Thus, a good law system should be adjusted by the quantity and quality of victim loss and misery ${ }^{12}$.

\footnotetext{
${ }^{9}$ Ibid.

${ }^{10}$ Lukman Santoso and Bustanul Arifin. (2017). "Perlindungan Perempuan Korban Kekerasan Perspektif Hukum Islam". Journal de Jure 8( 2): 113.

${ }^{11}$ Philipus M. Hadjon. (2007). Perlindungan Hukum Bagi Rakyat, Peradaban. Jakarta, p. 34-35.

${ }^{12}$ Lilik Mulyadi. (2007). Kapita Selekta Hukum Pidana, Kriminologi, Dan Viktimologi. Jakarta: PT Djambatan.
} 
The decision of Sidoarjo District Court judge nomor : 889/Pid.Sus/2018/PN Sda,because it only pay attention to the law as structure, it provides quite heavy sentence of 4 years, 6 months and a fine payment of 120 million rupiah, because criminal sanctions and payment will also be burdened by victim.

Siti Homzah,stated that inside the family, the violence that occurs related to different status and roles of husband and wife, therefore, most of the violence are exploitation and dominating ${ }^{13}$.Similar opinion explained by Budiawati Supangkatinside ${ }^{14}$, who stated that man is the head of family.This assumption caused by the ideology of men as a stronger side and women is weaker side.

Unfortunately, government attentions are not yet reach the maximum of law enforcement. As what explained by Lieta Vina Tania ${ }^{15}$, victims of crime consider as forgotten people in Criminal Justice System. government should beobligedto putattentiontotherightsofvictims in adjustingcriminalacts. There should be equality before the law which means the law must be consider on victim's interest apart from being a witness who knows a crime, the position of victim as a legal subject who has an equal position is also important.

In a criminal case settlement, it was found that many crime victims lacked adequate legal protection, both immaterial and material protection. Victims of crime only placed as evidence that provides information without any protection provided. ${ }^{16}$.

\section{CONCLUSION}

After examined the legal fact of literature review and analyze it, therefore the researcher consider husband activities on selling his wife by illegal sex/threesome should not be include in human trafficking punishment.Because normatively, it is not relevant, furthermore the condition of that family is not really well, thus the sanction of 4 (four) years, 6 (six) months and the fine charge of 120 Million is not demanded well because the victim will become a victim and she does not get physical and mental support during criminal period, becomes a victim for the second time because she must pay a fine of 120 MillionRupiahs.

Furthermore, there are some related recommendation that law enforcer such as (prosecutor and judges) on building their cases have to consider and understand the existed legal fact and regulation (positive law), whether it from philosophical basic, or substantial regulation of Indonesian constitution, without any exception. And payattention to the victim position that is still related to family (wife), don't let the victim become more victimize because they have to accept the punishment as she did not get any alimony from family and she has to pay her family criminal fine. Thus, to handle this kind of problem there should be based on Domestic Violence Court.

\section{Bibliography}

Books:

Gosita, Arif. (1989). Masalah Perlindungan Anak. Jakarta: CV Akademika Pressindo.

\footnotetext{
${ }^{13}$ Munandar Sulaiman and Siti Homzah. (2010). Kekerasan Terhadap Perempuan Tinjauan Dalam Berbagai Disiplin Ilmu Dan Kasus Kekerasan, p. 4.

${ }^{14}$ Ibid.

${ }^{15}$ Tania, "Analisis Perspektif Viktimologi Terhadap Korban Tindak Pidana Pemalsuan Dokumen Tenaga Kerja Wanita."

${ }^{16}$ Arif Gosita. (1989). Masalah Perlindungan Anak. Jakarta: CV Akademika Pressindo.
} 
Hadjon, Philipus M. (2007). Perlindungan Hukum Bagi Rakyat, Peradaban. Jakarta.

IOM Indonesia. (2006). Fenomena Trafficking Manusia Dan Konteks Hukum Internasional. Jakarta.

Meilisa, Hilda. "Istri Yang Dijual Suami Untuk Threesome Di Sarangan Hamil 6 Bulan." DetikNews. Last modified 2019. Accessed September 16, 2019. https://news.detik. com/berita-jawa-timur/d-4668648/istri-yang-dijual-suami-untuk-threesome-disarangan-hamil-6-bulan.

Mulyadi, Lilik. (2007). Kapita Selekta Hukum Pidana, Kriminologi, Dan Viktimologi. Jakarta: PT Djambatan.

Pound, Roscoe. (2012). The Ideal Element in Law. The Ideal Element In Law.

Sapardjaja, Komariah Emong. (2002). Ajaran Sifat Melawan Hukum Materiil Dalam Hukum Pidana Indonesia. Bandung: Alumni.

Sulaiman, Munandar, and Siti Homzah. (2010). Kekerasan Terhadap Perempuan Tinjauan Dalam Berbagai Disiplin Ilmu Dan Kasus Kekesaran.

Yulia, Rena. Viktimologi: Perlindungan Hukum Terhadap Korban Kejahatan. Bandung: Graha Ilmu, 2010.

Journal articles:

Santoso, Lukman, and Bustanul Arifin. (2017). "Perlindungan Perempuan Korban Kekerasan Perspektif Hukum Islam.” Journal de Jure 8 (2): 113.

Tania, Lieta Vina. (2018). “Analisis Perspektif Viktimologi Terhadap Korban Tindak Pidana Pemalsuan Dokumen Tenaga Kerja Wanita." Jurnal Fakultas Hukum Universitas Lampung Bandar Lampung 6, (4). 